\title{
Late Holocene temperature variability in Tasmania inferred from borehole temperature data
}

\author{
Asadusjjaman Suman ${ }^{1,2,3}$, Fiona Dyer ${ }^{1,3}$, and Duanne White ${ }^{1,3}$ \\ ${ }^{1}$ Institute for Applied Ecology, University of Canberra, Canberra, Australia \\ ${ }^{2}$ Department of Agricultural Engineering, Patuakhali Science and Technology University, Patuakhali, Bangladesh \\ ${ }^{3}$ Murray-Darling Basin Futures Collaborative Research Network, University of Canberra, Canberra, Australia
}

Correspondence to: Asadusjjaman Suman (sumanpstu@gmail.com)

Received: 29 November 2016 - Discussion started: 15 December 2016

Accepted: 25 April 2017 - Published: 2 June 2017

\begin{abstract}
Thirty-six borehole temperature-depth profiles were analysed to reconstruct the ground surface temperature history (GSTH) of eastern Tasmania for the past 5 centuries. We used the singular value decomposition method to invert borehole temperatures to produce temperature histories. The quality of borehole data was classified as high or low based on model misfit. The quality of the borehole data was not dependent on topography or land use. Analysis reveals that three to five high-quality borehole temperature-depth profiles were adequate to reconstruct robust paleotemperature records from any area.

Average GSTH reconstructed from Tasmanian boreholes shows temperature increases about $1.2 \pm 0.2^{\circ} \mathrm{C}$ during the past 5 centuries. Reconstructed temperatures were consistent with meteorological records and other proxy records from Tasmania during their period of overlap. Temperature changes were greatest around the north-east coast and decreased towards the centre of Tasmania. The extension of the East Australian Current (EAC) further south and its strengthening around the north-east coast of Tasmania over the past century was considered a prime driver of warmer temperatures observed in north-east Tasmania.
\end{abstract}

\section{Introduction}

Reconstructions of past temperatures are essential for understanding the trajectory of future environmental change, especially as regards distinguishing between natural variability and anthropogenic effects on the earth's climate (Hulme et al., 1999; St. Jacques et al., 2010; Soltwedel et al., 2015). The late Holocene is an important time period as it contains some major global and regional climatic variability, i.e. the Medieval Warm Period (MWP; Polovodova et al., 2011; Quamar and Chauhan, 2014), the Little Ice Age (LIA; Mann, 2002; Ponce et al., 2017), and 20th-century global warming, during a period when large-scale climate parameters such as ocean circulation and ice sheet extent were broadly similar to today. There is progress in hemispheric (Beltrami and Bourlon, 2004; Neukom and Gergis, 2011) and global (Huang et al., 2000) average temperature estimation over the last millennia, but there are still significant uncertainties in understanding regional responses to global anthropogenic effect (Mann et al., 2009).

A dearth of paleotemperature records limits knowledge of past climate during the late Holocene in the Southern Hemisphere and particularly Australia (Jansen et al., 2007; Jones and Mann, 2004) in comparison with the Northern Hemisphere (Mann and Jones, 2003; Neukom and Gergis, 2011). In Australia, proxies used to reconstruct past terrestrial temperature history are clustered in Tasmania (Colhoun, 2000; Cook et al., 2000; Fletcher and Thomas, 2010; Mackenzie and Moss, 2014; Rees and Cwynar, 2010), the eastern tropics (Moss et al., 2012, 2013; Moss and Neil, 2011; Petherick et al., 2013), and the west coast of Australia (Gergis et al., 2016; Kuhnert et al., 1999, 2000), which means they do not provide representative cover of the diverse climates across the continent. Paleotemperature reconstructions from borehole records have the potential to supplement existing climate proxy data and increase the spatial density of historical climate records across the Australian continent. However, in many areas of Australia and indeed worldwide, the borehole data available to reconstruct past temperatures is limited and 
the number of boreholes required to reconstruct robust past temperature has not been established.

Tasmania is an island located $240 \mathrm{~km}$ to the south of the mainland of Australia, between 41 and $43^{\circ} \mathrm{S}$. Tasmania is positioned in an area that is subject to significant climate variability and change. Components of global circulation patterns, such as the East Australian Current (EAC), Leeuwin Current (LC), Tasman Front (TF), and El Niño-Southern Oscillation (ENSO), play a major role in south-east Australia and the Tasmanian climate (Forootan et al., 2016; Hamilton, 2006; Herraiz-Borreguero and Rintoul, 2011; Meuleners et al., 2008; O'Kane et al., 2011). At the same time, global warming during the 20th century is observed to be accelerating and likely influencing local climate processes, which is thought to be contributing to temperature rise and environmental change in Tasmania (Colhoun, 2000; Fletcher and Thomas, 2010; Rees and Cwynar, 2010).

High-quality instrumental data records in Tasmania are usually only available for the last 100 years (Bureau of Meteorology, 2016a), and records of this length are restricted to around Hobart and Launceston. The reconstruction of past temperature histories prior to the 1900's thus relies on climate proxies such as tree rings (Cook et al., 2000, 2006), chironomids (Rees et al., 2008; Rees and Cwynar, 2010), vegetation types (Colhoun, 2000; Mackenzie and Moss, 2014), lake levels (Colhoun et al., 1999; Fletcher and Thomas, 2010), and sediment (Townsend and Seen, 2012), each of which have drawbacks for reconstructing past climatic variability (Huang et al., 2000). For instance, in many cases climate reconstruction from lake level or pollen records are often a record of dry or wet conditions rather than the quantification of past temperature history. Further, measurement of the magnitude and temporal variation in past climate from these proxies is quite challenging.

The earth's sub-surface contains a memory of past surface temperatures (Beltrami and Mareschal, 1995; Chouinard et al., 2007; Pollack et al., 2006). The shallow sub-surface temperature is governed by the time-varying boundary condition at the surface and by the heat emitted from the earth's interior. In the absence of surface temperature fluctuations, an "ideal" equilibrium temperature profile in homogenous bedrock is characterized by a linear increase with depth. When surface temperature variations occur, a thermal front propagates downward (Appleyard, 2005; Pollack and Huang, 2000). The rate of downward propagation depends on subsurface rock thermal diffusivity $(k)$, which in general for rock is very low $\left(k \approx 10^{-6} \mathrm{~m}^{2} \mathrm{~s}^{-1}\right.$; Gosselin and Mareschal, 2003a). Thus, the downward propagation of climatic signals is slow; i.e. the past 200 years of record is contained in the topmost $100 \mathrm{~m}$, and the post glacial record is contained within 1000-2000 m (Gosselin and Mareschal, 2003a; Huang et al., 2000). The measurements of present-day temperatures down boreholes can therefore extract a record of past surface temperature conditions. This method is not limited to geographical location; it can theoretically be recon- structed at any location by drilling a borehole and recording precise downhole temperatures. These records provide direct but low temporal-resolution paleoclimate records that complement both the climate proxies and instrumental records.

Using borehole data, past temperature history has been reconstructed in many areas across the world: in North America (Beltrami et al., 2003; Chouinard et al., 2007; Gosselin and Mareschal, 2003b; Guillou-Frottier et al., 1998; Mareschal and Beltrami, 1992), Europe (Bodri et al., 2001; Bodri and Čermák, 1998; Bodri and Dövényi, 2004; Kukkonen and Clauser, 1994; Mareschal and Vasseur, 1992), Asia (Akkiraju and Roy, 2011; Goto et al., 2005; Roy et al., 2002; Roy and Chapman, 2012), and Australia (Appleyard, 2005; Pollack et al., 2006) as well as in hemisphere and global averages (Beltrami and Bourlon, 2004; Huang et al., 2000; Pollack and Huang, 2000). However, the quality of borehole data needed to reconstruct past temperature history and the minimum number of high-quality boreholes required to reconstruct plausible past temperature history is not well addressed in the literature. Additionally, characterizing the spatial variation in paleotemperatures is limited to studies in Canada (Beltrami et al., 2003; Gosselin and Mareschal, 2003a, b) and the Northern Hemisphere (Beltrami and Bourlon, 2004), but it is essential to examine other parts of the globe particularly in different climatic context.

Using a borehole network from eastern Tasmania, this study investigates the quality of borehole data and the minimum number of boreholes required to reconstruct plausible past temperature records. In addition, we explore intraregional paleotemperature variability using the reconstructed Tasmanian paleotemperature record.

\section{Study region}

Tasmania is located at the southernmost extent of the Australasian continental plate. Tasmania was connected with the mainland of Australia during glacial periods (Colhoun et al., 1999; Rees et al., 2008) but is presently separated from mainland Australia by the $250 \mathrm{~km}$ wide Bass Strait (Jackson, 2005). In spite of its association with the mainland, Tasmania is dominated by oceanic climate.

Westerlies known as the Roaring Forties provide yearround precipitation in Tasmania (Rees and Cwynar, 2010). However, the amount of precipitation strongly varies from west (super-humid) to east (sub-humid/semiarid) (Colhoun, 2000; Fletcher and Thomas, 2010). The average (1961-1990) annual mean temperature is $10.4^{\circ} \mathrm{C}$, with an average annual maximum temperature of $14.7^{\circ} \mathrm{C}$ and an average annual minimum temperature of $6.0^{\circ} \mathrm{C}$ in Tasmania (Bureau of Meteorology, 2016b). Sporadic intrusions of cold air from Antarctica can produce frost and snow at any time of the year. On the other hand, dry and warm air from mainland Australia sometimes causes temperatures that may exceed $40^{\circ} \mathrm{C}$ (Rees et al., 2008). 


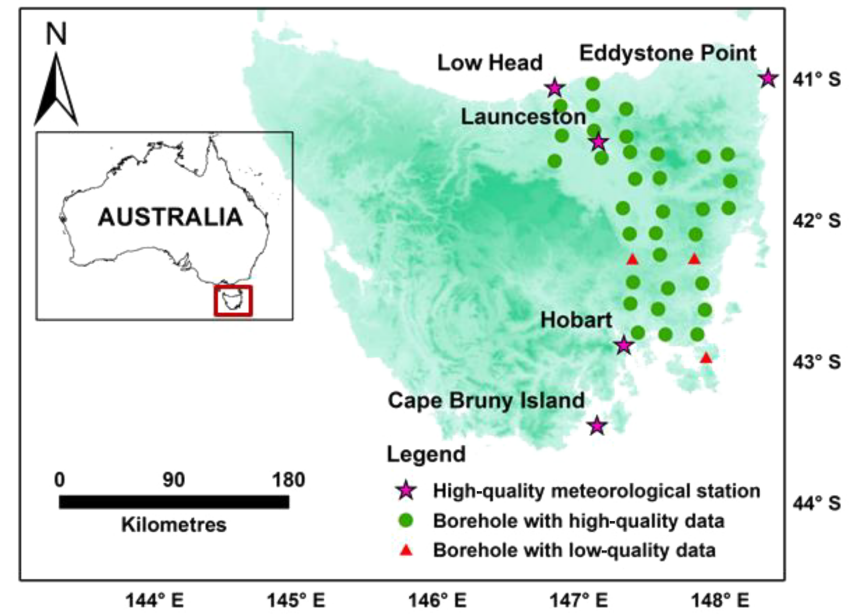

Figure 1. Location of 36 boreholes sites in Tasmania. High-quality ACORN-SAT (Bureau of Meteorology, 2016b) meteorological stations are shown by stars.

Borehole temperature and conductivity data required for paleotemperature reconstruction were available from 36 boreholes (Supplement Table S1) collected from eastern Tasmania between $41^{\circ} 10^{\prime}$ and $43^{\circ} 33^{\prime} \mathrm{S}$ and $146^{\circ} 22^{\prime}$ and $148^{\circ} 14^{\prime} \mathrm{E}$ (Fig. 1). Bedrock in eastern Tasmania is mainly dolerite and metasediment (McIntosh et al., 2012), and the landscape is generally of low altitude and relief. Native land cover is mainly evergreen eucalypt forest, alpine heathlands, cool temperate rainforest, and moorlands. However, much of the area has been modified or cleared for agriculture or been subject to forestry operations (Geoscience Australia, 2007).

\section{Methods}

Temperature reconstructions using data from boreholes rely on measuring the deviation from an ideal constant temperature gradient. The difference between the temperature measured down a borehole and a constant temperature gradient from the centre of the earth represents the total amount of warming and cooling (Fig. 2) in the ground after a change in surface boundary conditions (Gosselin and Mareschal, 2003a). The temporal variation and the magnitude of the temperature changes are related to the depth and departure from steady state.

The 36 borehole temperature-depth profiles from Tasmania were inverted individually to reconstruct the past ground surface temperature history (GSTH) of the region. The inversion of the borehole temperature profile is an operation that transforms a temperature-versus-depth profile at a given time (the time of measurement) into a temperature-versustime profile at a given depth. Basically, inversion yields a GSTH. The link between depth and time is through the thermal diffusivity and other thermophysical properties of the rock through which the climate signal is propagated. (a)

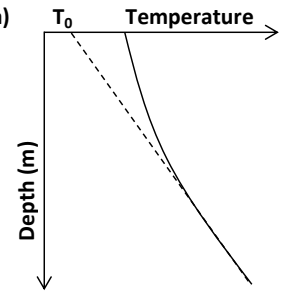

(b)

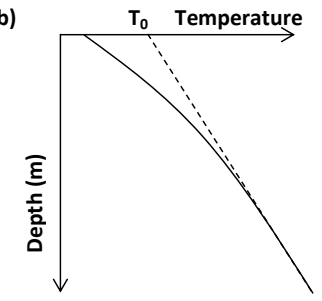

Figure 2. Schematic diagram of borehole temperature-depth profiles showing ground surface temperature (a) warming and (b) cooling. Dashed and Solid line indicates the steady-state and measured temperature respectively. $T_{0}$ represent ground temperature at steady-state condition.

The perturbation at depth $z, T(z)$, caused by temperature changes at the earth surface, can be expressed considering the thermal conductivity variations, as the superimposition of the equilibrium temperature and the perturbation $T_{t}(z)$ induced by temporal surface temperature condition (Beltrami et al., 1992):

$T(z)=T_{0}+q_{0} R(z)+T_{t}(z)$,

where $T_{0}$ is the equilibrium surface temperature, $q_{0}$ is the surface heat flow density, and $R(z)$ is the thermal resistance to depth $z$. The effect of heat production is small and can be neglected. In general, short period variations are filtered out by the earth. The surface temperature, estimated by the average surface temperature over $k$ time intervals of equal duration $\Delta$, can be expressed as

$T(t)=T_{k}(k-1) \Delta \leq t \leq k \Delta$.

Equation (1) can then be modified as

$\theta_{j}=\mathbf{A}_{j k} \boldsymbol{X}_{i}$

where $\theta_{j}$ is the measured temperature at depth $z_{j}, \boldsymbol{X}_{i}$ is a vector encompassing the unknowns $\left\{T_{0}, q_{0}, T_{1} \ldots T_{k}\right\}$, and $\mathbf{A}_{j k}$ is a matrix, each row of which contains 1 in the first column, the thermal resistance to depth $z_{j}$ in the second column, and the $K$ elements formed by evaluating the difference between complementary error functions at times $T_{k-1}=(k-1) \Delta$ and $T_{k}=k \Delta$ :

$\mathbf{A}_{j k+2}=\operatorname{erfc}\left\{\frac{z_{j}}{2 \sqrt{k t_{k-1}}}\right\}-\operatorname{erfc}\left\{\frac{z_{j}}{2 \sqrt{k t_{k}}}\right\}$.

Equation (4) is a linear equation that can be solved by singular variable decomposition (SVD; Beltrami et al., 1992; Beltrami and Mareschal, 1995; Mareschal and Beltrami, 1992; Menke, 1989).

Borehole temperature inversions were completed using a Matlab SVD script (Clauser and Mareschal, 1995; Mareschal and Beltrami, 1992) based on the above equations. The inversion technique computes no temperature change at the deepest point of the borehole and starting time of the simulation. 
Thus, the GSTH is reconstructed from the deviation of borehole temperatures from steady state considering no change at the deepest point.

Most of the Tasmanian boreholes used in this study were shallow, ranging in depth from about 200 to $300 \mathrm{~m}$. This depth can potentially record the last 500 years of temperature history. Therefore, we used a linear time step distribution, whereas for a longer history (>10 000 years) a logarithmic distribution is usual practice (Mareschal and Beltrami, 1992).

Prior to temperature inversions, where appropriate, borehole temperatures were corrected for variations in thermal conductivity. Most of the boreholes used for our temperature reconstructions were drilled through dolerite that has limited variations in thermal conductivity and thus required no temperature correction. Twelve boreholes were located in lithologies with variable thermal conductivity (indicated by * in Supplement Table S1), and temperature profiles were corrected to improve precision in GSTH reconstruction. For the 12 boreholes requiring correction, average thermal conductivity was calculated for all sub-surface lithologies, and subsequently the harmonic mean of thermal conductivity was calculated to have a single value for the borehole. Heat flow was calculated using all sub-surface thermal conductivity values and downhole temperature data were recalculated through back propagation using calculated heat flow and the harmonic mean of the thermal conductivity of the borehole.

The thermal diffusivity $(k)$ of rock is expressed by the following equation:

$k=\frac{\lambda}{c \times \rho}$,

where $\lambda$ is the thermal conductivity and, for most minerals and rocks, the product of $c \times \rho$ is about $2.3 \times 10^{6} \mathrm{~J} \mathrm{~m}^{-3} \mathrm{~K}^{-1}$ (Beardsmore and Cull, 2001). Small variation in thermal conductivity does not have a great effect on thermal diffusivity, nor the reconstruction of GSTH. In the present research, for simplicity thermal diffusivity of $1.0 \times 10^{-6} \mathrm{~m}^{-2} \mathrm{~s}^{-1}$ was used for all boreholes.

We also collected commonly measured topographic, geologic, and climatic data that may have an effect on past temperature reconstruction. Geographic character, i.e. slope, aspect, relief, and distance from the coast, were measured from the Shuttle Radar Topography Mission (SRTM) $30 \mathrm{~m}$ resolution digital elevation model (Rabus et al., 2003; Zyl, 2001) using ArcGIS v10.2.1. Land use and the change in land use since 1982 were compiled from Landsat, Google Earth satellite imagery and from Forestry Tasmania. Core samples and drill chips were used to determine the sub-surface lithology. Details of data compilation are described by Suman and White (2017). High-quality climate network data were used to assess local climate variations for the 20th century (Bureau of Meteorology, 2016b). In addition, we compared our reconstruction with tree rings (Cook et al., 2000) and Southern
Hemisphere sea surface temperature using HadSTT 3.1.1.0 data (Kennedy et al., 2011).

\section{Results}

\subsection{Detection of reliable borehole data}

In principle, in a conductive thermal regime, a precise temperature inversion process will provide a modelled temperature-depth profile that coincides closely with the measured temperature-depth profile. Deviation between modelled and measured temperature-depth profiles indicates that the modelled GSTH is inaccurate or at least imprecise. Here, we test whether or not the misfit (i.e. difference) between measured and modelled temperature data down the borehole can be used as a guide to the reliability of any given borehole-derived GSTH (Fig. 3).

Normally, misfits are generated during inversion at every point throughout the borehole where measured data are available. We assessed two measures of model-data misfit to determine if they were a reliable means of measuring the quality of the borehole records. The first was "sumsq misfit" calculated as the sum of the squares of all misfit data, based on the sum of the variance between the model and measured data at each depth of temperature logging. The second method, termed "cumulative area misfit", was calculated in a similar way, but the misfit values were first smoothed to remove the high-frequency noise present in most borehole data. Smoothing was achieved with a low-pass filter that averaged 49 data points, 24 above and 24 below each value, at each temperature logging point. The smoothed misfit was then summed across each depth to produce the single cumulative area misfit value (Fig. 4). Based on sumsq and cumulative area misfit, we found three boreholes possessing lowquality borehole temperature data.

To test if the sum square and cumulative area misfit also provides a measure of the accuracy of the past temperature history, we conducted an empirical test. Each borehole GSTH was compared to the average from the 33 boreholes with high-quality temperature data. The average of the 33 borehole temperature profiles had previously been shown to have good agreement with the meteorological record (Suman and White, 2017) during their period of overlap. Thus, the difference between each borehole and the average could be considered to provide a reliable measure of the accuracy of each borehole temperature reconstruction.

Both the sumsq and cumulative area misfit correlate with differences in paleotemperature from average GSTH. So, both misfits could be used as basis of quantifying the accuracy of the borehole record. However, the cumulative area misfit was calculated from an average of $49 \mathrm{~m}$ (in general Tasmanian borehole temperature data were collected at $1 \mathrm{~m}$ intervals), which reduces the magnitude of any specific trends in the misfit data. Therefore, we consider that the cumulative area misfit provides the more reliable measure and 

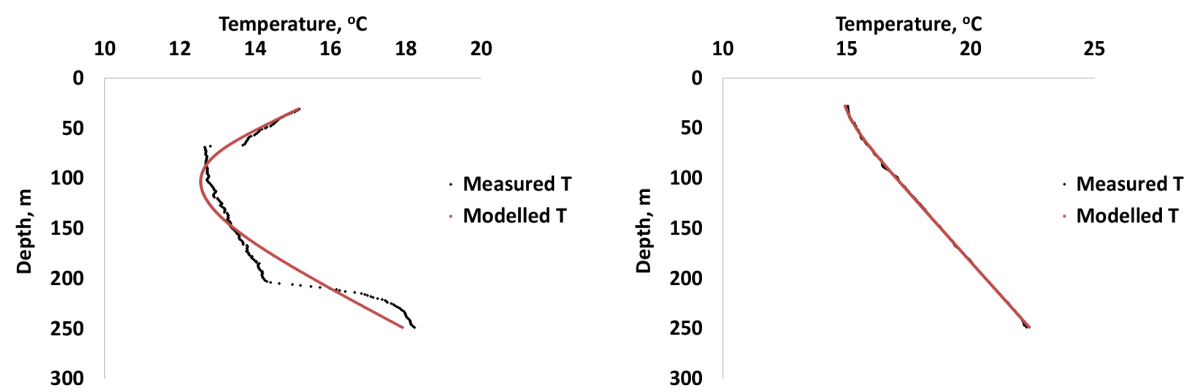

(a) Oatlands borehole

(b) Beaconsfield borehole

Figure 3. (a) High deviation between measured and modelled temperature-depth profile and borehole records classified as low quality. (b) Very low deviation between measured and modelled temperature-depth profile and borehole records classified as high quality.

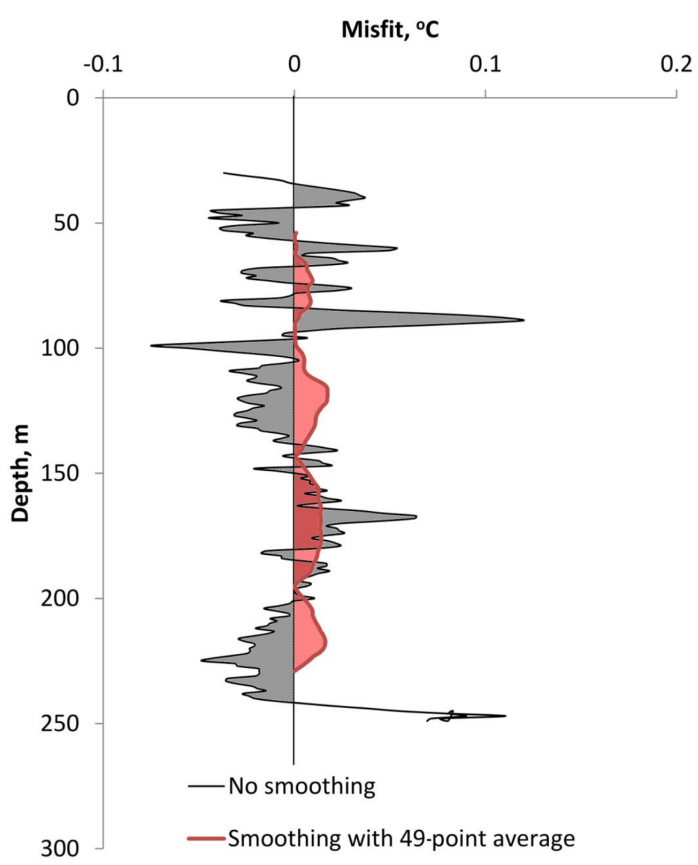

Figure 4. Misfit between measured and modelled temperature profiles at Beaconsfield. The raw misfit contains substantial highfrequency noise, while the smoothed misfit is much more representative of the low-frequency variations that are more significant for the accuracy of paleotemperature reconstructions. Sumsq misfit and Cumulative area misfit values referred to in the text are effectively the area between the curves and the $y$-axis of the unsmoothed and 49-point smoothed misfit values respectively.

will use it from here on. Boreholes with low model misfit and lower differences in paleotemperature between individual and average reconstruction of all boreholes are considered better quality.

Based on the cumulative area misfit and the greatest temperature change (GTC) in each borehole, we classified the Tasmanian borehole data set into two broad groups: boreholes with high- and low-quality data. GTC was calculated from the reconstructed time series considering maximum minus minimum temperature change based on the long-term average (1500 to $1700 \mathrm{AD}$ ). Data from 3 out of 36 boreholes produced very high cumulative area misfits and inconsistent temperature change; therefore, they were categorized as low quality (Fig. 5). These three profiles may be affected by groundwater flow or downhole temperature measurement errors during logging. The remainder produce low cumulative area misfit and consistent temperature change and therefore were classified as being of high quality (Fig. 5).

In boreholes with high-quality data, the GTC varies from 0.57 to $1.92^{\circ} \mathrm{C}$, with a relatively low cumulative area misfit in last 500 years (Fig. 5). In this category, most boreholes show comparably consistent GTC during the last 500 years. The five best boreholes - Nunamara, Ben Lomond, Swan, Lisle, and Beaconsfield - with the lowest area misfit $\left(<0.01 \mathrm{~m}^{2} \mathrm{~m}^{-1}\right.$; Fig. 5 , holes are circled) can be considered to provide a robust reconstruction of past temperature from that region. In boreholes with low-quality data, the GTC varies considerably, from 2.5 to $6.5^{\circ} \mathrm{C}$, and displays a high model misfit in the last 500 years (Fig. 5).

The availability of borehole data is limited in many areas and drilling boreholes is costly. So, understanding the quality of borehole data and the number of boreholes required to reconstruct a plausible past temperature history is useful for the interpretation of the existing records. Theoretically, boreholes with lowest area misfits are free of non-climatic perturbation that can provide plausible past temperature history, and they are less variable with the average high-quality borehole reconstruction.

Standard deviation can be used to measure variability in GTC in different groups. The standard deviation of GTC from boreholes with low $\left(<0.01 \mathrm{~m}^{2} \mathrm{~m}^{-1}\right)$, moderate $(0.01-$ $\left.0.1 \mathrm{~m}^{2} \mathrm{~m}^{-1}\right)$, and high $\left(>0.1 \mathrm{~m}^{2} \mathrm{~m}^{-1}\right)$ area misfits increases from 0.2 to 0.4 and $2.0^{\circ} \mathrm{C}$ respectively. Therefore, five boreholes (Fig. 5) with an area misfit $<0.01 \mathrm{~m}^{2} \mathrm{~m}^{-1}$ show the lowest variation in their GTC, and variation increases significantly within boreholes with increasing area misfit. 


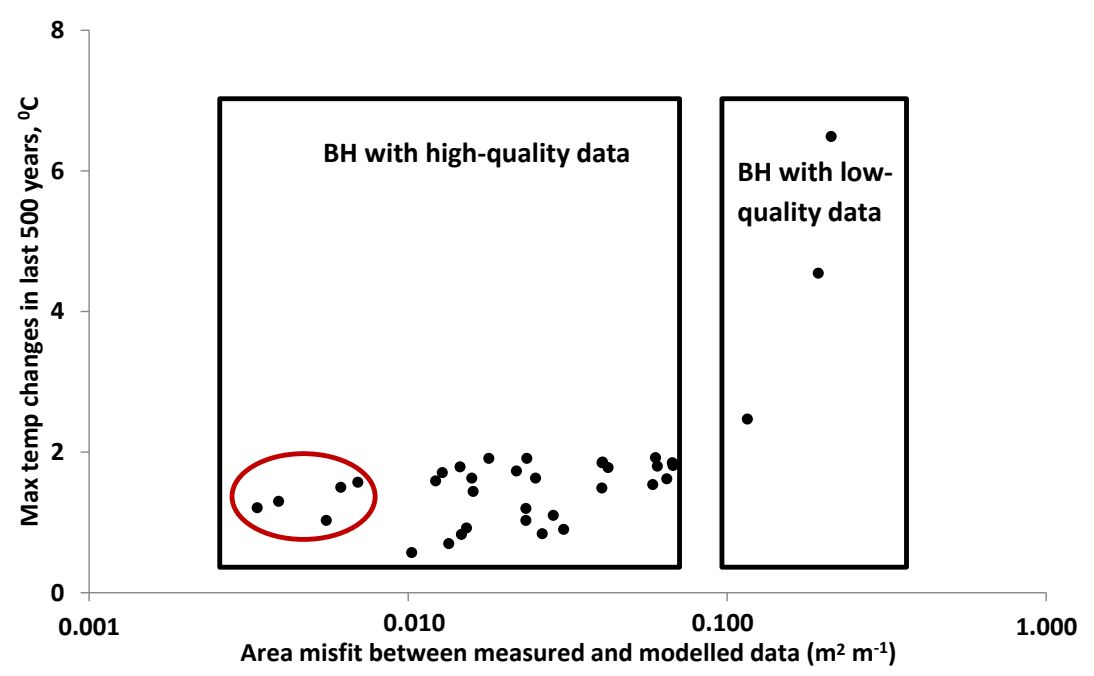

Figure 5. GTC with an area misfit between measured and modelled data.

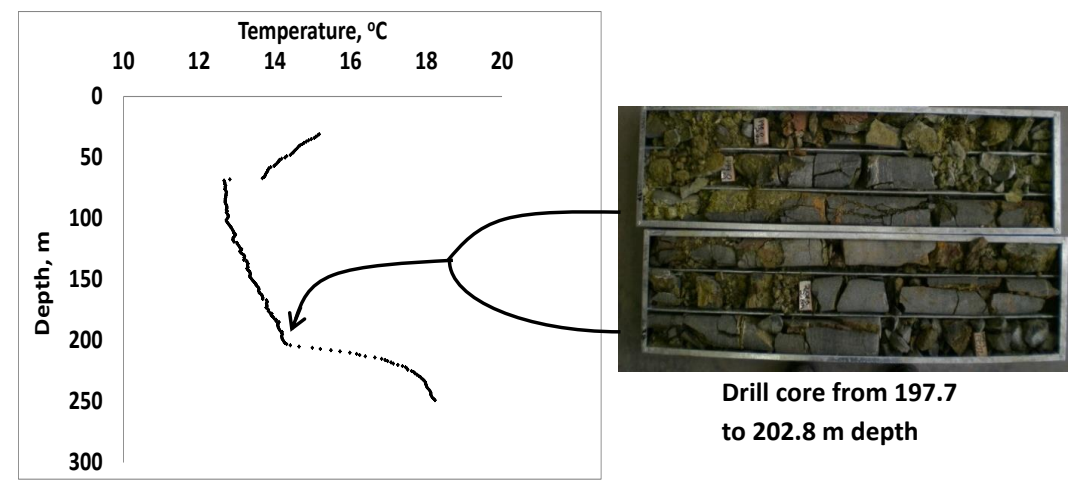

(a)

(b)

Figure 6. (a) Borehole temperature profile (Oatlands borehole) suspected to have been affected by groundwater movement at $\sim 200 \mathrm{~m}$. The upper discontinuity may be due to horizontal groundwater flow. (b) Broken drill core from 197.7 to $202.8 \mathrm{~m}$. The high frequency of fractures suggests highly permeable rock and groundwater movement (Photo courtesy of Oatlands borehole, KUTh energy, Tasmania).

Beside this, the strength of the correlation among time series decreases with the increase in area misfit of boreholes. The correlation matrix shows the highest correlation among the best three to five boreholes with an area misfit $<0.01 \mathrm{~m}^{2} \mathrm{~m}^{-1}$. Moreover, these three to five boreholes' average temperature record correlates highly with the surrounding average meteorological record $(r=0.95 ; p$ value $=0.00)$ during their period of overlap and other proxy results. Therefore, we concluded that three to five boreholes with an area misfit $<0.01 \mathrm{~m}^{2} \mathrm{~m}^{-1}$ can be used for plausible past temperature reconstruction from any other area. Boreholes with moderate area misfits may also provide reliable GSTH but would require twice this number of boreholes to provide a similarly precise GSTH measurement.

To check whether there was a geophysical basis for the misfit observed in the boreholes with low-quality data, we also checked the shape of the downhole temperature records (Fig. 6a) and the core retrieved from these boreholes (Fig. 6b). In each of the three boreholes with low-quality data, it appears that it was the function of groundwater that affected temperature-depth profiles. This is indicated by profiles with an inconsistent temperature gradient, a break in the temperature profile, missing data, etc., and corresponding to fractured drill core indicating permeable lithologies (Fig. 6).

We also investigated whether the extent of model-data misfit correlated with geographic or topographic properties. Lithology appears to correlate with borehole data-model misfit. Analysis shows that boreholes which are located in sedimentary rocks produce lower area misfit in comparison to boreholes which are located in dolerite or in mixed lithologies (Fig. 7). However, the significance of the correlation is not clear, as many of the factors likely to produce perturbed temperature profiles (e.g. rock fracture density, uncorrected 


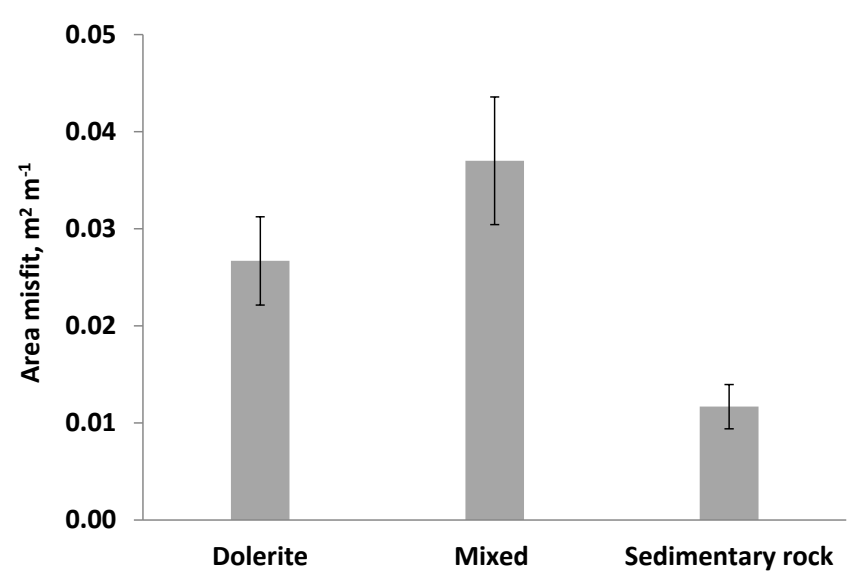

Figure 7. Relationship between area misfit and borehole subsurface lithology. Error bars represent standard errors, with a $1 \sigma$ confidence interval.

variability in thermal conductivity) are higher in the sedimentary rocks.

Topographic and geographic factors such as elevation, slope, aspect, relief, easting, and distance from coast were not significantly correlated with cumulative area misfit (Table $1 ; p$ values are calculated at a $95 \%$ confidence interval). However, the northing is significantly correlated with the cumulative area misfit ( $p$ value $=0.03$ ). Boreholes with low area misfits are located in a higher northing area. This is perhaps due to the pattern of sub-surface lithology. The south-east area of Tasmania is rich in Parmeener and dolerite, whereas the north-east region is dominated by mixed geology i.e. Devonian granites, Ordovician Mathinna beds, etc. (Seymour et al., 2007). Beside this, most of the sediment boreholes are located in the south of Tasmania.

\subsection{Reconstruction of GSTH}

Thirty-three borehole temperature-depth profiles (Supplement Fig. S1) show a relatively consistent temperature gradient throughout the holes, with the exception of temperature increases toward the surface, indicative of recent warming. The reconstructed GSTH based on these boreholes show relatively stable temperature trends (Fig. 8) until the end of the 19th century. As the diffusive nature of the borehole temperature record filters out high-frequency variability, the temporal resolution of the record decreases exponentially with time. Thus, the data should be considered to provide stable means. There was no change in centennial-mean temperatures in the borehole reconstruction between the 15th and 19th centuries, and this was followed by a sharp increase in the 20th century (Fig. 8). This is consistent with other studies from Australia (Appleyard, 2005; Pollack et al., 2006), Canada (Beltrami et al., 1992, 2003; Chouinard et al., 2007; Gosselin and Mareschal, 2003a), Europe (Bodri et al., 2001; Bodri and Dövényi, 2004; Veliciu and Šafanda, 1998), and
Table 1. The relationship between potential geographical and topographical attributes with cumulative area misfit.

\begin{tabular}{lcc}
\hline Attribute & $\begin{array}{r}R \text {-squared } \\
\text { (area) }\end{array}$ & $P$ values \\
\hline Elevation & 0.025 & 0.38 \\
Distance from coast & 0.000 & 0.98 \\
Slope & 0.036 & 0.29 \\
Aspect & 0.011 & 0.56 \\
Relief & 0.021 & 0.42 \\
Northing & 0.146 & 0.03 \\
Easting & 0.014 & 0.51 \\
\hline
\end{tabular}

Asia (Goto et al., 2005; Roy et al., 2002; Roy and Chapman, 2012).

Most of the reconstructed Tasmanian GSTH from boreholes recorded a consistent increase in temperature since 1900. Theoretically, low-resolution reconstruction from borehole temperature data is not capable of displaying any decadal variability in past temperature history. However, seven holes considered to have high-quality data (Rocherlea, Epping, Temple Bar, Weymouth, Elizabeth, Frankford, and Tunbridge) show cooling during the mid-20th century before rapid warming in the late 20th century. Most of these boreholes are located in consistent dolerite (Rocherlea, Epping, Temple Bar, and Elizabeth) and mudstone (Weymouth) lithologies that are likely to have produced a relatively more reliable temperature record than mixed lithology boreholes. We did not find any relation between these boreholes and topographic and geologic factors to cluster them separately.

We consider these patterns probably either due to sitespecific truncation error or random variability in the borehole temperature data. Although the meteorological record on a national scale in Australia also shows a cooling event during the mid-20th century (Karoly and Braganza, 2005; Nicholls, 2003; Nicholls and Collins, 2006), it is very unlikely to correlate this mid-20th-century cooling event with the abovementioned seven-borehole cooling event during the early to mid-20th century.

The average reconstructed ground surface temperature warming was found to be $1.2 \pm 0.2^{\circ} \mathrm{C}$ in the last 500 years across eastern Tasmania with most of this warming occurring in the late 20th century (Fig. 8). Average borehole reconstruction correlates significantly $(r=0.9$ and $p$ value $=0.00)$ at the 0.05 level with the surrounding average meteorological record.

The reconstructed changes in temperature were observed to vary spatially across the region (Fig. 9). A higher temperature change is observed around the north-east coast of Tasmania. We did not find any significant relation between the GTC and geologic and topographic factors. Details were reported in Suman and White (2017). Thus, only climatic factors and land use are responsible for this observed spatial variability. 


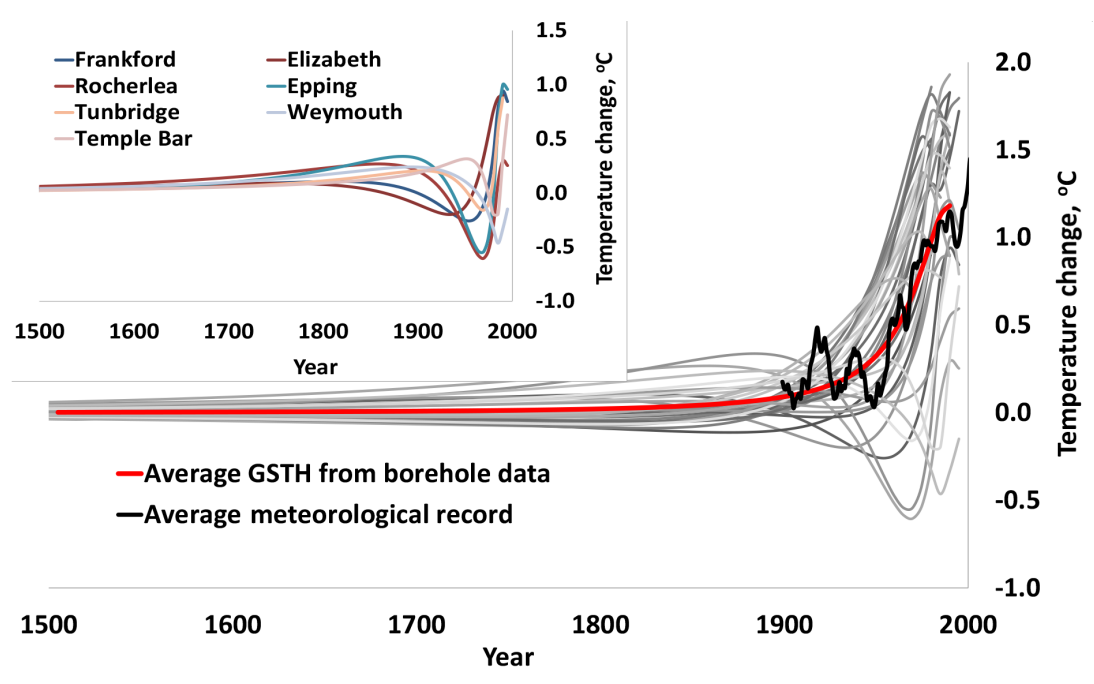

(a)

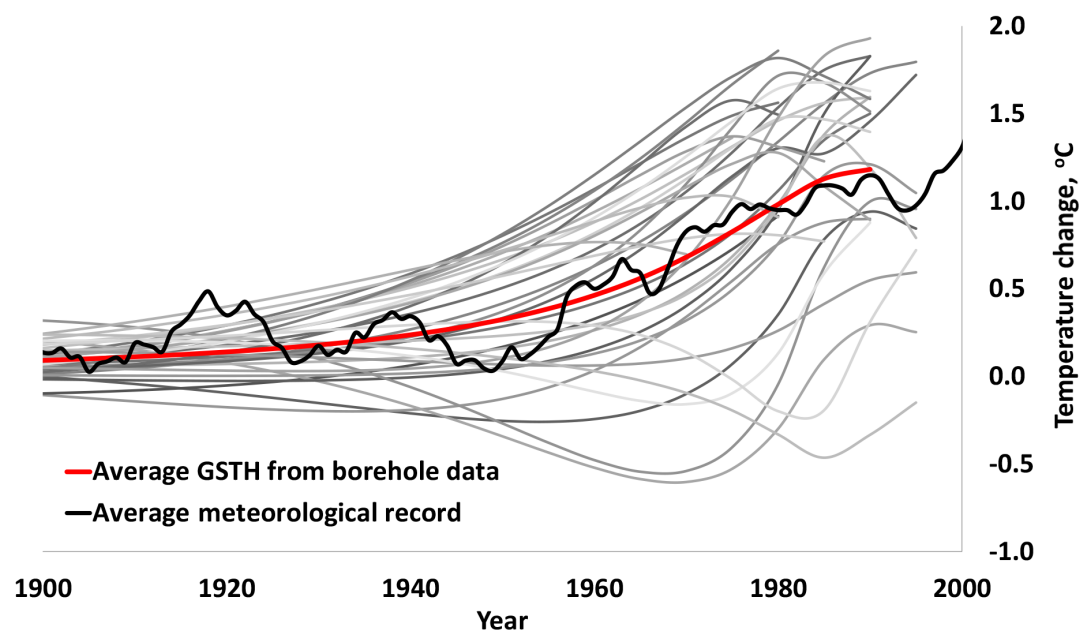

(b)

Figure 8. Reconstructed GSTH from the Tasmanian high-quality data set. The red line shows average reconstruction from 33 boreholes and temperature anomalies based on the long-term average (1500 to $1700 \mathrm{AD}$ ). The black line represents average temperatures from meteorological data compiled from the surrounding five (Low Head no. 091293, Launceston no. 091311, Hobart no. 094029, Cape Bruny Island no. 094010, and Eddystone Point no. 092045) meteorological stations. Temperature change in the meteorological record was calculated from the mean of 1961 to 1990. Inset in panel (a): reconstruction from seven boreholes shows early to mid-20th-century cooling before rapid warming at the end of the 20th century. Individual and average borehole reconstructions with an average meteorological record are only shown for the 20th century for visibility (b).

Higher temperature change was found close to the coast compared with the midlands of Tasmania. The distance of the borehole from the coast is moderately correlated (negatively) with the GTC (Fig. 10). The relation is statistically significant at the 0.05 level ( $p$ value $=0.03$ )

\subsection{Variation due to land use}

Our study showed that land use has a limited spatial and temporal correlation with reconstructed temperatures. The re- constructions found slightly higher temperature changes using data from the boreholes located in grass area compared with those from forested areas, and the difference between them was higher at the end of 20th century. This was established using only the available land use data since 1980, which provided a limited opportunity to test spatial and temporal variation in paleotemperature based on land use change during the whole period of simulation since 1500 AD. However, the available data period shows that temperature change 


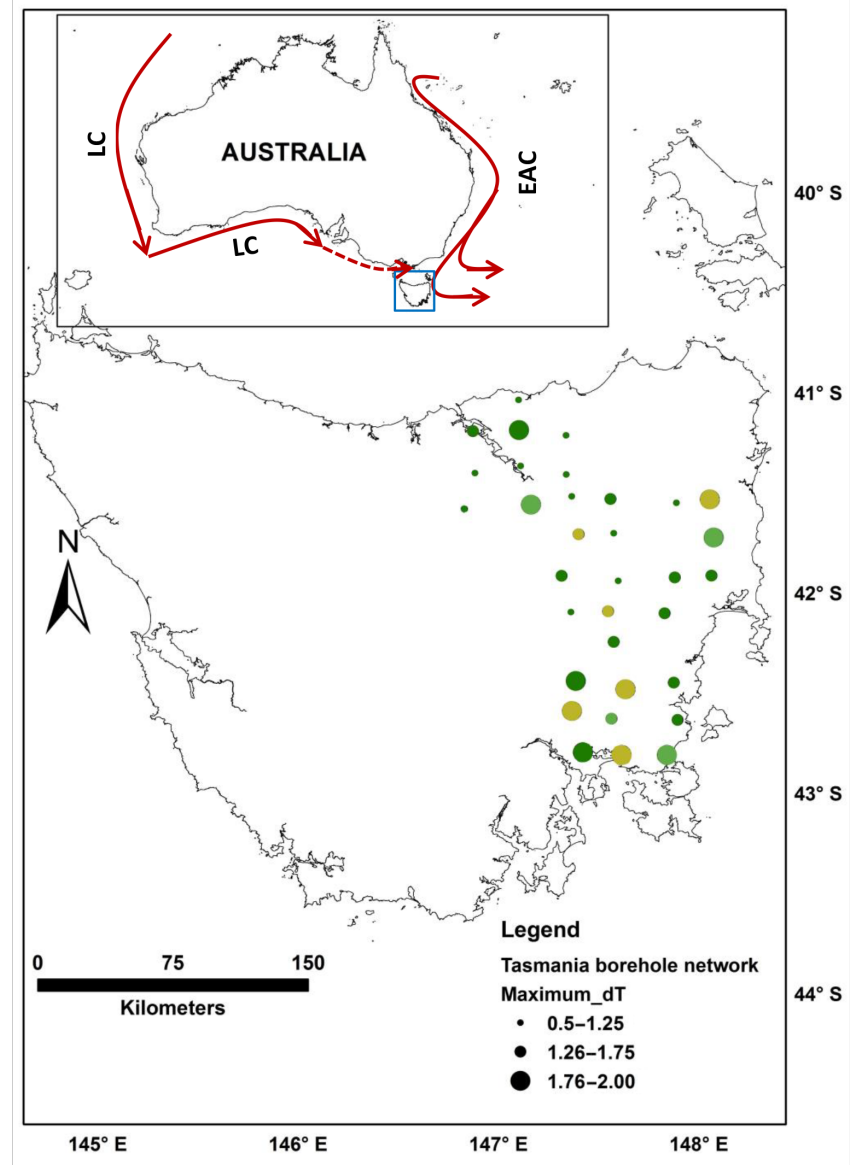

Figure 9. Spatial variation in regional GTC in Tasmania during the past 500 years. The colours represent area misfit between measured and modelled downhole temperature data. Dark green: <0.04; pale green: 0.04-0.06; khaki: $>0.06$ (to 0.08 ) $\mathrm{m}^{2} \mathrm{~m}^{-1}$. Symmetric representation and flow directions of two major current systems around Australia are presented in the inset: the EAC and the LC (dashed line represents the extent of Leeuwin current during La Niña phase).

due to land use is statistically insignificant (independent sample $t$ test; $p$ value $=0.21)$ at the 0.05 level.

Pollen records from western Tasmania (Colhoun et al., 1999; Colhoun, 2000), the central plateau (Hopf et al., 2000), and eastern Tasmania (Mackenzie and Moss, 2014) show that Tasmanian vegetation did not change greatly during the mid to late Holocene. In addition, historical analysis also shows that, despite changes in species composition (Fensham, 1989), the overall landscape vegetation structure of midland Tasmania has not change sufficiently in the last few hundred years to affect the observed trends in GSTH. Therefore, it is less likely that vegetation changed prior to the 1980s is the driver of the spatial variation in paleotemperature in Tasmania.

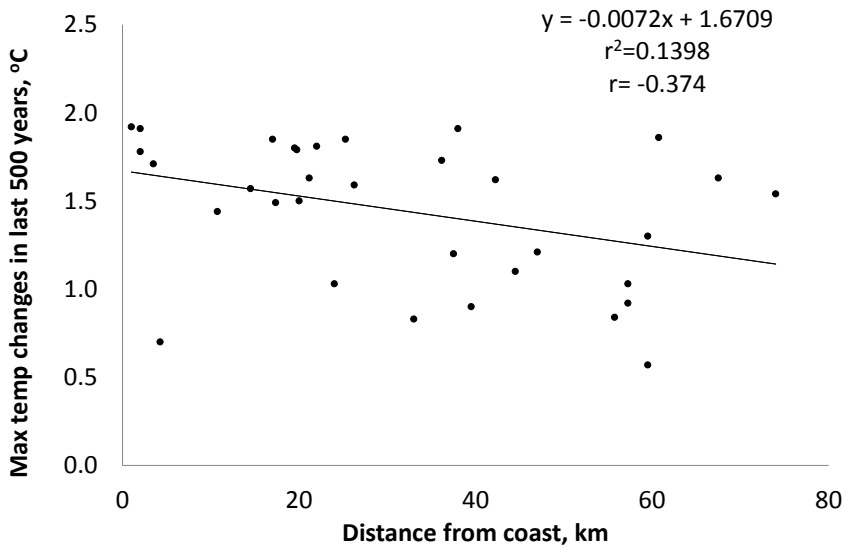

Figure 10. Correlation between the GTC and the distance of the borehole location from the coast.

\section{Discussion}

The detection of good boreholes is very important for the reconstruction of a plausible temperature history as well as for the area where the availability of borehole data is limited. In this study, we proposed a new technique to define the quality of borehole data for paleotemperature reconstructions based on area misfit. We have found that boreholes with low area misfit produce consistent temperature changes in the last 500 years (Fig. 5). These temperature changes are comparable to average meteorological data from the same area during their period of overlap (Fig. 8). Analysis shows that it is possible to reconstruct robust paleotemperature by $\sim$ three to five high-quality boreholes from a region with an area misfit $<0.01 \mathrm{~m}^{2} \mathrm{~m}^{-1}$ depth of borehole.

Temperature changes during the past 5 centuries on the continental scale are in found in North America $(1.2 \mathrm{~K})$, South America $(1.4 \mathrm{~K})$, Europe $(0.8 \mathrm{~K})$, Africa $(0.8 \mathrm{~K})$, and Asia (1.2 K) (Huang et al., 2000; Pollack and Huang, 2000); these are comparable to our reconstructed average GTC.

\subsection{Comparison with proxy result}

Reconstructed temperature records using the Tasmanian borehole data agree well $(r=0.839$ and $p$ value $=0.000)$ with records of the Southern Hemisphere sea surface temperature (SST; Fig. 11) during their period of overlap. SST anomalies are relative to 1961-1990 and increased about $1.0^{\circ} \mathrm{C}$ during in the 20th century (Kennedy et al., 2011).

Temperature reconstruction from our boreholes also agrees fairly well with the Mt Read Huon pine dendrochronology (Cook et al., 2000) $(r=0.333$ and $p$ value $=0.001$, Fig. 11). The low temporal resolution (roughly centennial) of the borehole GSTH in the early part of the record means that the decadal variability seen in the reconstructed tree ring result (Cook et al., 2000) is not observed in the boreholes, leading to a low Pearson correlation coef- 


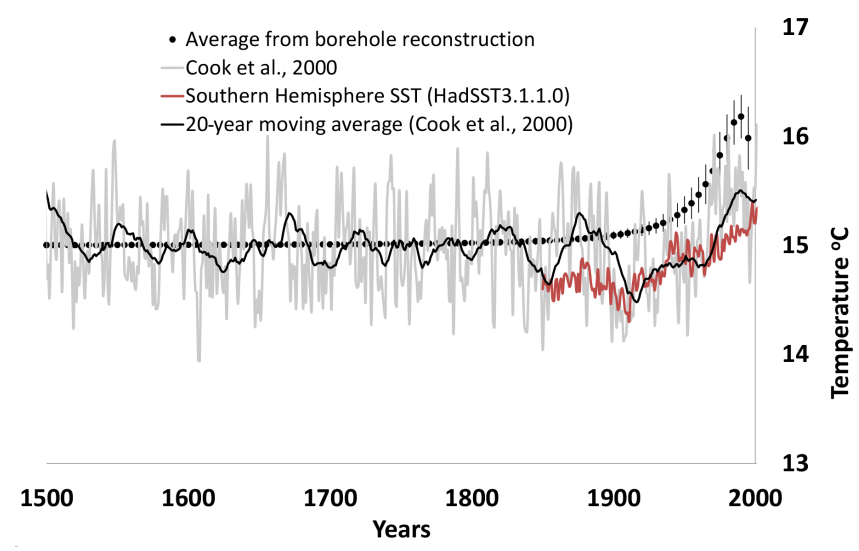

Figure 11. Comparison of temperature histories reconstructed using borehole data with those from Tasmanian dendroclimatological reconstruction and Southern Hemisphere sea surface temperature data.

ficient. However, importantly, both boreholes and tree ring temperature reconstructions show a relatively stable centennial average temperature between 1500 and 1850 AD. Some correlation between boreholes and tree rings is also seen with a short (20-30-year) cool period in the early 20th century, with seven boreholes recording temperature cooling at this time that may correlate with the $\sim 0.5^{\circ} \mathrm{C}$ dip seen in the tree ring record (Cook et al., 2000). Finally, both our borehole reconstruction and tree ring records show rising temperatures toward the end of the record, although the magnitudes differ, with the boreholes on the north-east Tasmanian coast recording larger increases than the tree rings on the central upland plateau.

Temperature reconstruction using the chironomid record from Platypus Tarn in Tasmania also shows an increase in temperature of about $1{ }^{\circ} \mathrm{C}$ during the 19th and 20th century (Rees and Cwynar, 2010). The 20th-century warming captured by the chironomid proxy data is comparable to the borehole reconstruction. Pollen records (Anker et al., 2001; Fletcher and Thomas, 2010; Mackenzie and Moss, 2014) and lake records (Colhoun et al., 1999; Hopf et al., 2000) from Tasmania indicate recent warming or drying with stable climate during the late Holocene, which also shows some correlation with our borehole reconstruction.

\subsection{Spatial variation}

Ocean climatology is an important driver of the Tasmanian climate. The LC flows more strongly during La Niña phase and extends further east (Fig. 9, Reeves et al., 2013; Petherick et al., 2013) up to around the north-west coast of Tasmania. However, during El Niño years, the LC flows weakly and the current does not reach around Tasmania. Due to the sporadic strength of the LC around the north coast of Tasmania, it may have a limited effect on temperature change in that region.
The EAC (O'Kane et al., 2011; Ridgway and Dunn, 2003; Wilkin and Zhang, 2007) brings warm water around eastern Australia from north to south and flows eastwards into the Tasman Sea from the east coast of Tasmania (Fig. 9; Ridgway and Hill, 2009; Ridgway and Dunn, 2003). During austral summer time (January-May), the EAC brings warm water towards the north and east coast of Tasmania (Ridgway, 2007; Ridgway and Dunn, 2003); this may be a driver of higher temperature changes around the north-east coast of Tasmania.

Borehole records were not available on the west coast of Tasmania. Therefore, it was difficult to show any trend in temperature change from the far west to the east of Tasmania from borehole data alone. However, comparing a 20-year low-pass-filtered tree ring reconstruction from Mount Read, western Tasmania (Cook et al., 2000), with boreholes from north-eastern Tasmania shows that the mean borehole reconstruction was significantly (independent sample $t$-test $p$ value $=0.02$ ) higher during the 20th century.

The observation record from Maria Island, located on the east coast of Tasmania, shows that the region became both saltier and warmer, with mean trends of 0.34 psu century $^{-1}$ and $2.28^{\circ} \mathrm{C}$ century ${ }^{-1}$ over the 1944 to 2002 period (Ridgway and Hill, 2009). The same study also shows that the EAC strengthened and extended further southward during this period. The enhanced warming in the region is also indicated by the result from SST using the Comprehensive OceanAtmosphere Data Set (Smith and Reynolds, 2003). Beside these, model studies also estimate the extension of the EAC towards the south and its strengthening around the northeast of Tasmania (Cai et al., 2005; Cai, 2006). In addition, the warming of the Tasman Sea around north-eastern Tasmania is also indicated by the movement of some temperaturesensitive marine species (Centrostephanus rodgersii, Carcinus maenas) from the north tropics towards the south in the last century (Ling et al., 2008; Pittock, 2003; Thresher et al., 2003).

Our GSTH provides evidence that this offshore warming produced by an enhanced EAC increased temperatures on land. Borehole temperature increases during the 20th century were higher near the coast when compared to the overall borehole data set (Fig. 9). Therefore, it is more likely that the southward extension and strengthening of the warm EAC influenced the pattern of temperature changes in north-eastern Tasmania during the 20th century. The high-quality meteorological network also shows higher temperature change on the north-eastern Tasmanian coast during the 20th century (dataavailable period, Fig. 12) (Bureau of Meteorology, 2016b) in compared to the other midland stations. Our data refine the geographic extent of this enhanced warming and suggest that it has been most important within $\sim 50 \mathrm{~km}$ of the north-east coast. 


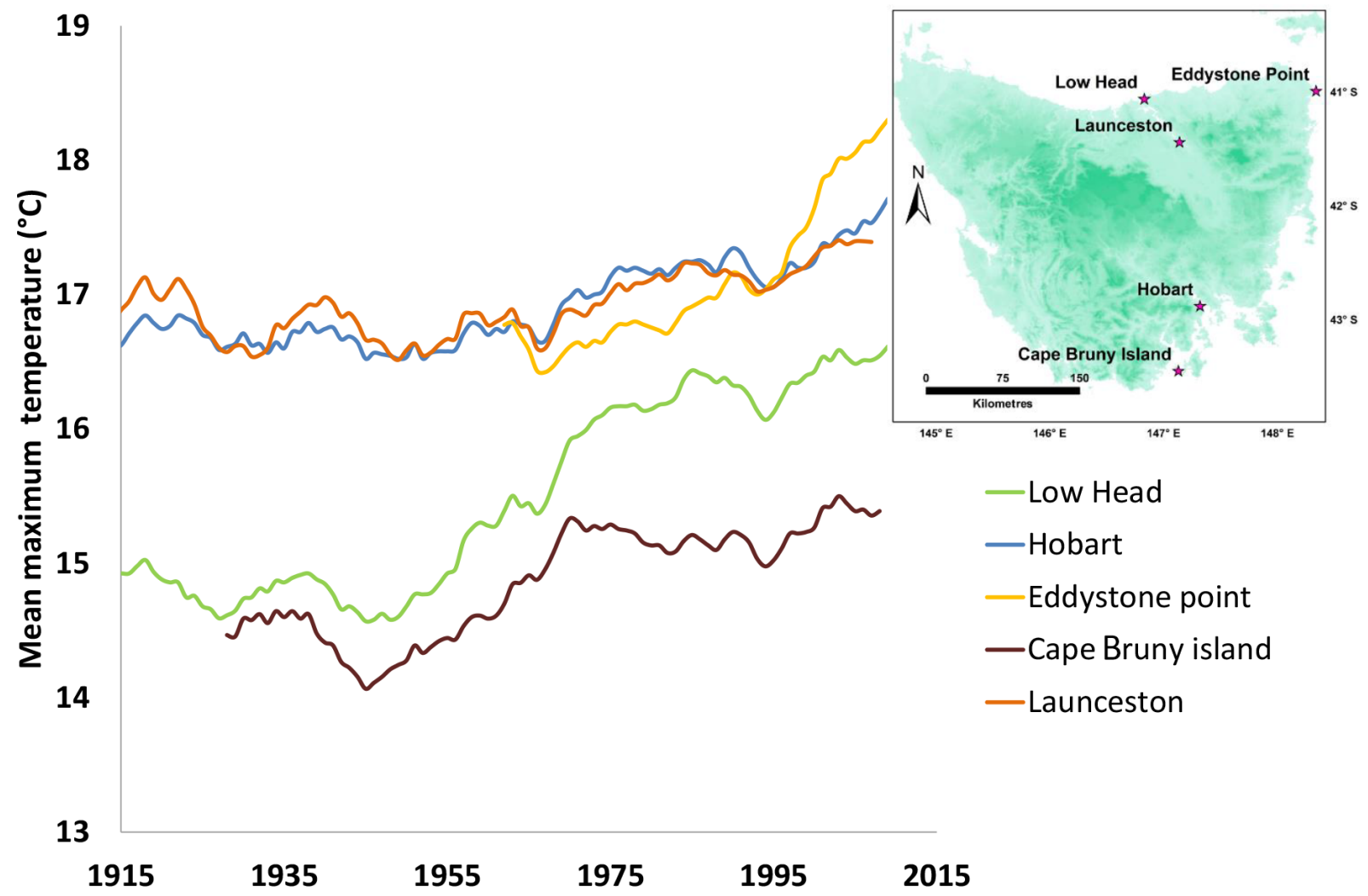

Figure 12. Meteorological record from eastern Tasmania (Bureau of Meteorology, 2016b).

\section{Conclusion}

Temperature-depth profiles from 36 boreholes across eastern Tasmania were analysed to reconstruct GSTH for the past 5 centuries. Detailed analysis reveals that not all borehole temperature-depth data are suitable for inversion to reconstruct GSTH. Borehole data can be categorized as being of high or low quality based on sum squared and cumulative area misfit. While sub-surface lithology may be a factor in determining borehole quality, we did not find any specific relationship between the quality of the borehole with topography and land use. Overall, between three and five high-quality boreholes with an area misfit $<0.01 \mathrm{~m}^{2} \mathrm{~m}^{-1}$ temperature-depth profiles are enough to reconstruct robust paleotemperature from any area.

Our 5-century temperature reconstruction is characterized by a temperature increase of $1.2 \pm 0.2^{\circ} \mathrm{C}$, with most of the warming occurring during in the 20th century. The average temperature reconstructions from boreholes agree well with high-resolution Tasmanian surface air temperature during their period of overlap. GSTH reconstructed from boreholes also agrees well with other proxy reconstructions from the Tasmanian region. Reconstructed temperature profiles shows higher temperatures around the coast and decrease towards the centre of Tasmania. Warmer ocean temperatures due to the extension of the EAC towards the south and the strength- ening around north-east Tasmania over the past century may be the driver of a warmer north-eastern coast of Tasmania.

Data availability. All borehole temperature and thermal conductivity data were collected from KUTh Energy Ltd., Australia. Data are available in the Supplement.

\section{The Supplement related to this article is available online at https://doi.org/10.5194/cp-13-559-2017-supplement.}

Competing interests. The authors declare that they have no conflict of interest.

Acknowledgements. The research is funded by the Australian Government Research Training Program Scholarship and MurrayDarling Basin Futures Collaborative Research Network and is part of the "Predicting the response of water quality and groundwater dependent ecosystems to climate change and land management practices: an integrated modelling approach" project. We acknowledge J. C. Mareschal, Geotop, University of Quebec, Canada, for his support in base model for inversion. We acknowledge KUTh Energy Ltd., Australia, for all borehole temperature and geology data. 
Edited by: A. Lorrey

Reviewed by: two anonymous referees

\section{References}

Akkiraju, V. V. and Roy, S.: Geothermal climate change observatory in south India 1: Borehole temperatures and inferred surface temperature histories, Phys. Chem. Earth, 36, 1419-1427, 2011.

Anker, S. A., Colhoun, E. A., Barton, C. E., Peterson, M., and Barbetti, M.: Holocene vegetation and paleoclimatic and paleomagnetic history from Lake Johnston, Tasmania, Quaternary Res., 56, 264-274, 2001.

Appleyard, S.: Late Holocene temperature record from southwestern Australia: evidence of global warming from deep boreholes, Aust. J. Earth Sci., 52, 161-166, 2005.

Beardsmore, G. R. and Cull, J. P.: Crustal Heat Flow: A Guide to Measurments and Modelling, Cambridge University Press, Cambridge, UK, 2001.

Beltrami, H. and Bourlon, E.: Ground warming patterns in the Northern Hemisphere during the last five centuries, Earth Planet. Sci. Lett., 227, 169-177, 2004.

Beltrami, H. and Mareschal, J. C.: Resolution of ground temperature histories inverted from borehole temperature data, Global Planet. Change, 11, 57-70, 1995.

Beltrami, H., Jessop, A., and Mareschal, J.C.: Ground temperature histories in eastern and central Canada from geothermal measurements: Evidence of climatic change, Palaeogeogr. Palaeocl., 98, 167-184, 1992.

Beltrami, H., Gosselin, C., and Mareschal, J.C.: Ground surface temperatures in Canada: Spatial and temporal variability, Geophys. Res. Lett., 30, 1499, https://doi.org/10.1029/2003GL017144, 2003.

Bodri, L. and Čermák, V.: Last 250 years climate reconstruction inferred from geothermal measurements in the Czech Republic, Tectonophysics, 291, 251-261, 1998.

Bodri, L. and Dövényi, P.: Climate change of the last 2000 years inferred from borehole temperatures: data from Hungary, Global Planet. Change, 41, 121-133, 2004.

Bodri, L., Cermak, V., and Kukkonen, I. T.: Climate change of the last 2000 years inferred from borehole temperatures: data from Finland, Global Planet. Change, 29, 189-200, 2001.

Bureau of Meteorology: Climate Data Online, available at: http: //www.bom.gov.au/climate/data/?ref=ftr/, last access: 18 June $2016 \mathrm{a}$.

Bureau of Meteorology: ACORN-SAT station data and network: Long-term temperature record, Australian Climate Observations Reference Network - Surface Air Temperature, available at: http://www.bom.gov.au/climate/change/acorn-sat/\#tabs= Data-and-networks/, last access: 19 June 2016b.

Cai, W.: Antarctic ozone depletion causes an intensification of the Southern Ocean super-gyre circulation, Geophys. Res. Lett., 33, $1-4,2006$

Cai, W., Shi, G., Cowan, T., Bi, D., and Ribbe, J.:The response of the Southern Annular Mode, the East Australian Current, and the southern mid-latitude ocean circulation to global warming, Geophys. Res. Lett., 32, 1-4, 2005.

Chouinard, C., Fortier, R., and Mareschal, J. C.: Recent climate variations in the subarctic inferred from three borehole tempera- ture profiles in northern Quebec, Canada, Earth Planet. Sci. Lett., 263, 355-369, 2007.

Clauser, C. and Mareschal, J. C.: Ground temperature history in central Europe from borehole temperature data, Geophys. J. Int., 121, 805-817, 1995.

Colhoun, E. A.: Vegetation and climate change during the Last Interglacial-Glacial cycle in western Tasmania, Australia, Palaeogeogr. Palaeocl., 155, 195-209, 2000.

Colhoun, E. A., Pola, J. S., Barton, C. E., and Heijnis, H.: Late Pleistocene vegetation and climate history of Lake Selina, western Tasmania, Quatern. Int., 57-58, 5-23, 1999.

Cook, E. R., Buckley, B. M., D’Arrigo, R. D., and Peterson, M. J.: Warm-season temperatures since $1600 \mathrm{BC}$ reconstructed from Tasmanian tree rings and their relationship to large-scale sea surface temperature anomalies, Clim. Dynam., 16, 79-91, 2000.

Cook, E. R., Buckley, B. M., Palmer, J. G., Fenwick, P., Peterson, M. J., Boswijk, G., and Fowler, A.: Millennia-long tree-ring records from Tasmania and New Zealand: a basis for modelling climate variability and forcing, past, present and future, J. Quaternary Sci., 21, 689-699, 2006.

Fensham, R. J.: The pre-European vegetation of the Midlands, Tasmania: a floristic and historical analysis of vegetation patterns, J. Biogeogr., 16, 29-45, 1989.

Fletcher, M. S. and Thomas, I.: A quantitative Late Quaternary temperature reconstruction from western Tasmania, Australia, Quaternary Sci. Rev., 29, 2351-2361, 2010.

Forootan, E., Awange, J. L., Schumacher, M., Anyah, R. O., van Dijk, I. J. M., and Kusche, J.: Quantifying the impacts of ENSO and IOD on rain gauge and remotely sensed precipitation products over Australia, Remote Sens. Environ., 172, 50-66, 2016.

Geoscience Australia: Understanding bushfire: trends in deliberate vegetation fires in Australia, GA report, Canberra, Australia, 2007.

Gergis, J., Neukom, R., Gallant, A. J. E., and Karoly, D. J.: Australasian temperature reconstructions spanning the last millennium, J. Climate, 29, 5365-5392, 2016.

Gosselin, C. and Mareschal, J. C.: Variations in ground surface temperature histories in the Thompson Belt, Manitoba, Canada: environment and climate changes, Global Planet. Change, 39, 271 284, 2003a.

Gosselin, C. and Mareschal, J. C.: Recent warming in northwestern Ontario inferred from borehole temperature profiles, J. Geophys. Res., 108, 2452, https://doi.org/10.1029/2003JB002447, 2003 b.

Goto, S., Hamamoto, H., and Yamano, M.: Climatic and environmental changes at southeastern coast of Lake Biwa over past 3000 years, inferred from borehole temperature data, Phys. Earth Planet. In., 152, 314-325, 2005.

Guillou-Frottier, L., Mareschal, J. C., and Musset, J.: Ground surface temperature history in central Canada inferred from 10 selected borehole temperature profiles, J. Geophys. Res., 103, 7385-7397, 1998

Hamilton, L. J.: Structure of the Subtropical Front in the Tasman Sea, Deep-Sea Res. Pt. I, 53, 1989-2009, 2006.

Herraiz-Borreguero, L. and Rintoul, S. R.: Regional circulation and its impact on upper ocean variability south of Tasmania, DeepSea Res. Pt. II, 58, 2071-2081, 2011.

Hopf, F. V. L., Colhoun, E. A., and Barton, C. E.: Late-glacial and Holocene record of vegetation and climate from Cynthia Bay, Lake St. Clair, Tasmania, J. Quaternary Sci., 15, 725-732, 2000. 
Huang, S., Pollack, H., and Shen, P.: Temperature trends over the past five centuries reconstructed from borehole temperatures, Nature, 403, 756-8, 2000.

Hulme, M., Barrow, E. M., Arnell, N. W., Harrison, P. A., Johns, T. C., and Downing, T. E.: Relative impacts of human-induced climate change and natural climate variability, Nature, 397, 688691, 1999.

Jackson, W. D.: The Tasmanian environment, in: Vegetation of Tasmania, edited by: Reid, J. B., Hill, R. S., Brown, M. J., and Hovenden, M. J., Australian Biological Resources Study, Tasmania, 11-34, 2005.

Jansen, E., Overpeck, J., Briffa, K. R., Duplessy, J. C., Joos, F., Masson-Delmotte, V., Olago, D., Otto-Bliesner, B., Peltier, W. R., Rahmstorf, S., Ramesh, R., Raynaud, D., Rind, D., Solomina, O., Villalba, R., and Zhang, D.: Climate Change 2007: The Physical Science Basis. Contribution of Working Group I to the Fourth Assessment Report of the Intergovernmental Panel on Climate Change, Cambridge University Press, Cambridge, UK, 433-497, 2007.

Jones, P. D. and Mann, M. E.: Climate over past millennia, Rev. Geophys., 42, 1-42, 2004.

Karoly, D. J. and Braganza, K.: Attribution of recent temperature changes in the Australian region, J. Climate, 18, 457-464, 2005.

Kennedy, J. J., Rayner, N. A., Smith, R. O., Parker, D. E., and Saunby, M.: Reassessing biases and other uncertainties in sea surface temperature observations measured in situ since 1850 , part 1: measurment and sampling uncertainties, J. Geophys. Res., 116, D14103, https://doi.org/10.1029/2010JD015218, 2011.

Kuhnert, H., Pätzold, J., Hatcher, B., Wyrwoll, K. H., Eisenhauer, A., Collins, L. B., Zhu, Z. R., and Wefer, G.: A 200-year coral stable oxygen isotope record from a high-latitude reef off Western Australia, Coral Reefs, 18, 1-12, 1999.

Kuhnert, H., Petzold, J., Wyrwoll, K. H., and Wefer, G.: Monitoring climate variability over the past 116 years in coral oxygen isotopes from Ningaloo Reef, Western Australia, Int. J. Earth Sci., 88, 725-732, 2000.

Kukkonen, I. and Clauser, C.: Simulation of heat transfer at the Kola deep-hole site: implications for advection, heat refraction and palaeoclimatic effects, Geophys. J. Int., 116, 409-420, 1994.

Ling, S. D., Johnson, C. R., Ridgway, K. R., Hobday, A. J., and Haddon, M.: Climate change drives range extension of a marine ecosystem engineer: Informing future patterns from correlations of the recent past, Glob. Chang. Biol., 15, 719-731, https://doi.org/10.1111/j.1365-2486.2008.01734.x, 2008.

Mackenzie, L. and Moss, P.: A late Quaternary record of vegetation and climate change from Hazards Lagoon, eastern Tasmania, Quatern. Int., 432, 58-65, https://doi.org/10.1016/j.quaint.2014.11.051, 2014.

Mann, M. E.: Little Ice Age, Encycl. Glob. Environ. Chang., 1, 504509, 2002

Mann, M. E. and Jones, P. D.: Global surface temperatures over the past two millennia, Geophys. Res. Lett., 30, 15-18, 2003.

Mann, M. E., Zhang, Z., Rutherford, S., Bradley, R. S., Hughes, M. K., Shindell, D., Ammann, C., Faluvegi, G., and Ni, F.: Global Signatures and Dynamical Origins of the Little Ice Age and Medieval Climate Anomaly, Science, 326, 1256-60, 2009.

Mareschal, J. C. and Beltrami, H.: Evidence for recent warming from perturbed geothermal gradients: Examples from eastern Canada, Clim. Dynam., 6, 135-143, 1992.
Mareschal, J. C. and Vasseur, G.: Ground temperature history from two deep boreholes in central France, Global Planet. Change, 98, 185-192, 1992.

McIntosh, P. D., Eberhard, R., Slee, A., Moss, P., Price, D. M., Donaldson, P., Doyle, R., and Martins, J.: Late Quaternary extraglacial cold-climate deposits in low and mid-altitude Tasmania and their climatic implications, Geomorphology, 179, 21-39, 2012.

Menke, W.: Geophysical Data Analysis: Discrete Inverse Theory, International Geophysics Service, Elsevier Academic Press Publication, Amsterdam, the Netherlands, 1989.

Meuleners, M. J., Ivey, G. N., and Pattiaratchi, C. B.: A numerical study of the eddying characteristics of the Leeuwin Current System, Deep-Sea Res. Pt. I, 55, 261-276, 2008.

Moss, P. T. and Neil, D.: Environmental Change at Myora Springs, North Stradbroke Island Over the Last Millenium, Proc. R. Soc. Queensl., 117, 113-140, 2011.

Moss, P. T., Cosgrove, R., Ferrier, A., and Haberle, S.: Holocene environments of the sclerophyll woodlands of the Wet Tropics of northeastern Australia, Terra Aust., 34, 329-341, 2012.

Moss, P. T., Tibby, J., Petherick, L., McGowan, H., and Barr, C.: Late Quaternary vegetation history of North Stradbroke Island, Queensland, eastern Australia, Quaternary Sci. Rev., 74, $257-$ 272, 2013.

Neukom, R. and Gergis, J.: Southern Hemisphere high-resolution palaeoclimate records of the last 2000 years, Holocene, 22, 501524, 2011.

Nicholls, N.: Continued anomalous warming in Australia, Geophys. Res. Lett., 30, 23-25, https://doi.org/10.1029/2003GL017037, 2003.

Nicholls, N. and Collins, D.: Observed climate change in Australia over the past century, Energy Environ., 17, 1-12, 2006.

O'Kane, T. J., Oke, P. R., and Sandery, P. A.: Predicting the East Australian Current, Ocean Model., 38, 251-266, 2011.

Petherick, L., Bostock, H., Cohen, T. J., Fitzsimmons, K., Tibby, J., Fletcher, M. S., Moss, P., Reeves, J., Mooney, S., Barrows, T., Kemp, J., Jansen, J., Nanson, G., and Dosseto, A.: Climatic records over the past $30 \mathrm{ka}$ from temperate Australia - a synthesis from the Oz-INTIMATE workgroup, Quaternary Sci. Rev., 74, 58-77, 2013.

Pittock, A. B.: Climate Change: An Australian Guide to the Science and Potential Impacts, in: Australian Greenhouse Office, Canberra, Australia, 2003.

Pollack, H. N. and Huang, S.: Climate reconstruction from subsurface temperatures, Annu. Rev. Earth Pl. Sc., 28, 339-365, 2000.

Pollack, H. N., Huang, S., and Smerdon, J. E.: Five centuries of climate change in Australia?: the view from underground, J. Quaternary Sci., 21, 701-706, 2006.

Polovodova, I., Nordberg, K., and Filipsson, H. L.: The benthic foraminiferal record of the Medieval Warm Period and the recent warming in the Gullmar Fjord, Swedish west coast, Mar. Micropaleontol., 81, 95-106, 2011.

Ponce, J. F., Borromei, A. M., Menounos, B., and Rabassa, J.: Late-Holocene and Little Ice Age palaeoenvironmental change inferred from pollen analysis, Isla de los Estados, Argentina, Quatern. Int., 1-9, https://doi.org/10.1016/j.quaint.2016.04.016, in press, 2017.

Quamar, M. F. and Chauhan, M. S.: Signals of Medieval Warm Period and Little Ice Age from southwestern Madhya Pradesh 
(India): A pollen-inferred Late-Holocene vegetation and climate change, Quatern. Int., 325, 74-82, 2014.

Rabus, B., Eineder, M., Roth, A., and Bamler, R.: The shuttle radar topography mission - a new class of digital elevation models acquired by spaceborne radar, ISPRS J. Photogramm. Remote Sens., 57, 241-262, 2003.

Rees, A. B. H. and Cwynar, L. C.: Evidence for early postglacial warming in Mount Field National Park, Tasmania, Quaternary Sci. Rev., 29, 443-454, 2010.

Rees, A. B. H., Cwynar, L. C., and Cranston, P. S.: Midges (Chironomidae, Ceratopogonidae, Chaoboridae) as a temperature proxy: a training set from Tasmania, Australia, J. Paleolimnol., 40, 1159-1178, 2008.

Reeves, J. M., Barrows, T. T., Cohen, T. J., Kiem, A. S., Bostock, H. C., Fitzsimmons, K. E., Jansen, J. D., Kemp, J., Krause, C., Petherick, L., and Phipps, S. J.: Climate variability over the last 35000 years recorded in marine and terrestrial archives in the Australian region: an OZ-INTIMATE compilation, Quaternary Sci. Rev., 74, 21-34, 2013.

Ridgway, K. R.: Seasonal circulation around Tasmania: An interface between eastern and western boundary dynamics, J. Geophys. Res.-Oceans, 112, 1-18, 2007.

Ridgway, K. R. and Dunn, J.: Mesoscale structure of the mean East Australian Current System and its relationship with topography, Prog. Oceanogr., 56, 189-222, 2003.

Ridgway, K. R. and Hill, K.: The East Australian Current, in: A Marine Climate Change Impacts and Adaptation Report Card for Australia 2009, edited by: Poloczanska, E. S., Hobday, A. J., and Richardson, A. J., NCCARF Publication 05/09, Tasmania, Australia, 2009.

Roy, S. and Chapman, D. S.: Borehole temperatures and climate change: Ground temperature change in south India over the past two centuries, J. Geophys. Res., 117, 1-12, 2012.

Roy, S., Harris, R., Rou, R., and Chapman, D.: Climate change in India inferred from geothermal observations, J. Geophys. Res., 107, 2138, https://doi.org/10.1029/2001JB000536, 2002.

Seymour, D. B., Green, G. R., and Calver, C. R.: The Geology and Mineral Deposits of Tasmania: a summary, Mineral Resources Tasmania, Australia, 2007.
Smith, T. M. and Reynolds, R. W.: Extended reconstruction of global sea surface temperatures based on COADS data (18541997), J. Climate, 16, 1495-1510, 2003.

Soltwedel, T., Bauerfeind, E., Bergmann, M., Bracher, A., Budaeva, N., Busch, K., Cherkasheva, A., Fahl, K., Grzelak, K., Hasemann, C., Jacob, M., Kraft, A., Lalande, C., Metfies, K., Nöthig, E. M., Meyer, K., Quéric, N. V., Schewe, I.,Włodarska-Kowalczuk, M., and Klages, M.: Natural variability or anthropogenically-induced variation? Insights from 15 years of multidisciplinary observations at the arctic marine LTER site HAUSGARTEN, Ecol. Indic., 65, 89-102, 2015.

St. Jacques, J. M., Sauchyn, D. J., and Zhao, Y.: Northern Rocky Mountain streamflow records: Global warming trends, human impacts or natural variability?, Geophys. Res. Lett., 37, 1-5, 2010.

Suman, A. and White, D.: Quantifying the variability of paleotemperature fluctuations on heat flow measurements, Geothermics, 67, 102-113, 2017.

Thresher, R. E., Proctor, C., Ruiz, G. M., Gurney, R., MacKinnon, C., Walton, W., Rodriguez, L., and Bax, N.: Invasion dynamics of the European shore crab, Carcinus maenas, in Australia, Mar. Biol., 142, 867-876, 2003.

Townsend, A. T. and Seen, A. J.: Historical lead isotope record of a sediment core from the Derwent River (Tasmania, Australia): A multiple source environment, Sci. Total Environ., 424, 153-161, 2012.

Veliciu, S. and Šafanda, J.: Ground temperature history in Romania inferred from borehole temperature data, Tectonophysics, 291, 277-286, 1998.

Wilkin, J. L. and Zhang, W. G.: Modes of mesoscale sea surface height and temperature variability in the East Australian current, J. Geophys. Res.-Oceans, 112, 1-14, 2007.

Zyl, J. V.: The Shuttle Radar Topography Mission (SRTM): a breakthrough in remote sensing of topography, Acta Astronaut., 48, 559-565, 2001. 